\title{
A Study on the Complementary Direction of Guidelines for Developing Green Conventions in Korea: Using Comparative Analysis among Domestic and Overseas Cases
}

\author{
Miseong Kim, Hyunji Moon, Minsu Chu and Yooshik Yoon* \\ Convention \& Exhibition Management, Graduate Shool of Hotel \& Tourism, KyungHee University, Seoul 02453, \\ Korea; mitning@khu.ac.kr (M.K.); hj_moon@khu.ac.kr (H.M.); cmsu@khu.ac.kr (M.C.) \\ * Correspondence: ysyn@khu.ac.kr
}

Received: 10 February 2020; Accepted: 16 April 2020; Published: 21 April 2020

check for updates

\begin{abstract}
As interests in sustainability have been increasing and discussions of environmental issues are ongoing globally, the MICE industry (Meeting, Incentive Travel, Convention, and Exhibition), which is attracting attention as a high value-added industry, also became an important part of the sustainability domain. Consequently, there has been a rise in hosting 'green conventions', or 'green MICE' which are designed to minimize all the negative impacts on the environment such as energy and water consumption. At some point, a large number of studies had been conducted for the development of green conventions, but most of them mainly used empirical methods. Although the Ministry of Environment has presented guidelines and some domestic exhibition convention centers have implemented strategies, they are not enough compared to overseas countries. This study aims to examine the latest guidelines to supplement the guidelines of Korea's green convention. In this regard, the study will use a comparative analysis method among the current guidelines of convention centers in Australia (Sydney), Canada (Vancouver), and the U.S.A (Detroit and San Francisco) and draw up complementary directions. As a result, we could draw out common items in the facility management and event planning and operation section. Some items were similar in all convention centers, but others were included in the guidelines of few centers only. This research is sure to be the academic background for developing related practices and standards for the future green convention in Korea. In addition, this study will have value in terms of investigating sustainable management in the convention industry as the importance of sustainability in the tourism industry emerges.
\end{abstract}

Keywords: green convention; guideline; exhibition and convention centers; sustainability; comparative analysis

\section{Introduction}

Numerous countries and cities around the world recognize the MICE (Meeting, Incentive Travel, Convention, and Exhibition) industry as a new growth engine industry, so they continue to expand investment and policy support in each sector of the MICE industry) [1]. McCartney and Gelen said that the competition to host the MICE is intensifying not only in Europe but also in Asia due to the positive assessment that it will greatly contribute to the internal and external image effects and economic revitalization of the host country [2]. However, in accordance with recent environmental problems and resource conflicts, social interest for sustainable growth increased [3]. In this respect, the MICE industry has also been discussing the concern regarding environmental issues such as its huge demand for natural resources, water, and energy [4]. The MICE industry inevitably causes environmental pollution in a variety of ways, such as air pollution caused by airplanes and cars, disposable items used 
at events, and energy fuel and waste used in convention facilities [5,6]. Accordingly, organizations such as UNEP, Convention Industry Council, and Professional Convention Management Association (PCMA) have begun to present guidelines and practices for eco-friendly conventions [7]. The U.N. Environment Program (UNEP) has also published a "Green Meeting Guide 2009", which is known to be the most representative guideline for green conventions [8].

In Korea, the Ministry of Environment announced the 'Guidelines for Environment-Friendly Management and Operation of Large-Scale International Conferences' and 'Guideline for Low-Carbon Events' for organizers planning various events [9]. In the case of convention centers, effective policies related to eco-friendly exhibitions and conventions are being announced, with COEX and Songdo Convensia leading the way [10]. As such, the domestic MICE market also shows a high interest in eco-friendly and sustainable and green conventions. However, the research on green convention facilities are insufficient. Various green MICE guidelines suggest specific action plans in terms of the operation of the event, but they are quite extensive in the operation of facilities at the convention center [11]. In response to climate change in line with rapidly changing environments, green MICE and its ripple effects have received attention. In consequence, the importance of choosing a green MICE facility is also increasing. Therefore, the convention and exhibition center, which is a representative MICE facility, should prepare and comply with environmental facility standards [12].

Discussions on the eco-friendly convention $[10,13]$ and the green convention $[14,15]$ became active in the 2010s. Lee, Kim, and Hwang derived the Green Convention Evaluation Index and the evaluation process through an actual case study [16]. Seong and Lee analyzed and presented guidelines for green MICE, which were published by international MICE-related industrial organizations, tourism-related departments, or CVB of the various countries [8]. Ha and Kim also analyzed the previously suggested guidelines for national and international green conventions and developed a guideline for convention centers in Seoul, Korea [15]. In addition to other prior studies, empirical studies were carried out related to green convention evaluation models, facility indicators and attributes, and case studies comparing green convention guidelines were conducted overall [17]. However, there is a lack of recent research on green conventions since the late 2010s.

It is important to compare with other societies to understand one society [18]. Since it is difficult to do an experiment with social policy development, a comparative study is the only alternative to find a solution $[19,20]$. Therefore, we tried to find a way to implement the green convention guideline by comparing it with other convention centers' guidelines of other countries. For choosing the comparison targets, we referred to the LEED certification system. LEED (Leadership in Energy and Environmental Design), an eco-friendly building certification system in the United States, was a certification tool developed in 1998 by the USGBC (US Green Building Council). The LEED v4 has been implemented since 2013 after several revisions since its initial development [21]. Furthermore, it has become one of the most widely recognized buildings in the world.

We selected four convention centers in three countries that have established and operated their own guidelines among convention centers that have been certified LEED Gold and Platinum for the past five years from 2015 to 2019 for comparison with a convention center in Korea. Additionally, we selected the Convensia among numerous convention centers in Korea, which developed their own guideline in 2013.

By comparing green convention guidelines, we will provide practical suggestions on the activation of the domestic convention center's green convention. In addition, we would like to fill the insufficient research areas of recent green convention guidelines and present the direction of operation of the eco-friendly convention center, thereby enhancing the eco-friendly awareness for revitalizing the domestic green convention industry.

\section{Literature Review}

\subsection{Guidelines for Green Conventions}

A green convention can be defined as an event that minimizes negative environmental issues and has a positive environmental impact at every stage of management and operations [22]. This 
concept may include all aspects of the convention, including the provision of $\mathrm{F} \& \mathrm{~B}$ (Food and Beverage) and transportation services and the procurement of convention materials [23]. With more environment-related rules and regulations appearing and individual environmental awareness growing, convention participants are increasingly looking for green conventions, and their sustainable demands rise [24-26].

Given the seriousness and importance of environmental concerns, conference facilities such as convention centers and meeting planners are increasingly striving to implement green strategies to reduce the environmental impact of conventions [27]. Thus, specific guidelines and agendas are being created by numerous associations and organizations to maintain the sustainability of convention events. Green convention guidelines are produced by international organizations such as the UNEP, Convention Industry Council (CIC), and national governments around Europe and the U.S., and they are used as recommendations to the convention industry and organizers [15].

One of the most representative guidelines for international organizations regarding the green MICE is the 'Green Meeting Guide 2009' published by the United Nations Environment Program (UNEP) which can be referenced in the process of venue selection, accommodation, food and beverage, conference room operation, transportation, exhibition, evaluation, and monitoring. The checklist is divided into three major sections: core recommendations (the vital recommendations related to environmental impact), going further (the detailed indicators of the green convention), and regional considerations (the indicators to meet the exact needs of the local meeting organizers) [28].

In addition, the Convention Industry Council (CIC), the largest organization in the convention industry, has formed a 'Green Meeting Task Force' to publish the 'Green Meetings Report' as a guideline for continued use by event organizers and suppliers [29]. Many convention centers such as the David L. Lawrence Convention Center in Pittsburgh, USA, the Vancouver Convention Center (Vancouver, Canada), and the Sydney Convention and Exhibition Centre (Sydney, Australia), have made great strides in 'going green' by not only designing eco-friendly facilities but also developing green convention standards and checklists [11]. Additionally, various convention centers continue to develop guidelines for sustainable conventions, among which the Moscone Center and the TCF center in the United States also operate convention centers according to the eco-friendly manuals as well as receiving LEED certification, an eco-friendly architecture certification system. Most of the guidelines developed by the Convention and Exhibition Center on its own are classified into items such as energy efficiency, air pollution, water use, waste reduction, catering, and use of products or materials required at the event, and specify detailed implementation manuals for each part.

By creating or developing the sustainable guidelines of the convention center, practitioners can prioritize the necessary practices and execute the convention events in more responsible ways [30]. According to Lee's research, both physical environmental factors and event management factors of the eco-friendly convention have been found to determine participants' satisfaction in common with both conference and exhibition participants [7]. For the effective hosting and operation of an eco-friendly convention, therefore, high-quality guidelines for the green convention are essential.

\subsection{Guidelines for Green Conventions in Korea}

In Korea, the Ministry of Environment announced 'Guidelines for Low Carbon Green Events' and 'Guidelines for Environmentally Friendly Management and Operation of Large International Conference' for hosting eco-friendly events in December 2008 [9,10,31]. Additionally, awareness of eco-friendly management such as obtaining green certification of the convention center is spreading on the premise of the friendly environment from the establishment to the operation of convention center [14].

As a result, effective policies related to eco-friendly exhibition conventions are being announced at the forefront of COEX and Songdo Convensia. COEX tried to show its stance to consider environmental issues in its exhibition operations actively. They use recycled land while operating eco-friendly management in earnest, and joined the company in contributing to environmental support programs 
when employees travel abroad, and also made efforts to use eco-friendly exhibition booth materials and clean up the air in the exhibition hall [32,33].

Additionally, Songdo Convensia was established for LEED certification as an eco-friendly building from the construction stage, and it became the first Asian Convention and Exhibition Center to acquire and operate LEED-NC (New Construction) certification grade. The company has also established three primary eco-friendly practices, including the operation of convention and exhibition events, green office, and green facility management based on LEED certification and reflected them in facility operation $[33,34]$.

\subsection{Certification for Leadership in Energy and Environmental Design}

Leadership in Energy and Environmental Design (LEED) certification is currently one of the most recognized green building certification programs, both nationally and internationally. It was developed by the U.S. Green Building Council (USGBC) to provide a scale on which green practices in the building could be measured and to provide support for owners wishing to achieve green standards [35]. In 2018, LEED was reorganized into LEED v4.1 and upgraded to a certification system that enhanced energy performance, enhanced health, and enhanced the importance of integrated building design [36].

Since its implementation in 1998, LEED has been the most widely used system for assessing sustainability achievements in new buildings and significant constructions [37]. As of 2016, the LEED certification system has served as the primary driver of certifying about 80,000 projects across 162 countries and enhancing awareness and participation in environmentally friendly buildings and eco-friendly designs as well as building evaluations [38].

The main items of the LEED assessment will be scored on several factors, including the energy use performance of the building, water protection performance, the quality of the indoor environment (IEQ), and materials of the building, and will be graded on certification, silver, gold, and platinum by the sum of these scores. The quality of the indoor environment is the most utilized among LEED certification systems. The importance of the LEED assessment items is increasingly emphasized by items related to thermal comfort, air quality, acoustic quality, and lighting quality, which are generally classified as significant factors in the classification of the physical environment [39].

There is currently no prior study of the domestic convention industry based on the LEED certification system. However, the LEED certification system was used when Han, Kim, and Shim conducted a foundational study to get stakeholders in the domestic convention center and convention industry to pay more attention to the company's sustainable management [3]. When examining the previous study with hotel and tourism studies, Jung, and Yoon confirmed the variables by assuming the LEED assessment items as environmental factors, tested whether the LEED evaluation items affected the hotel image, and tested whether the hotel image affected the potential customers' behavior [40].

\subsection{Green Convention Guideline Research}

Guidelines for green conventions are being established by international organizations such as UNEP, CIC, and national or regional governments across the U.S. and Europe (Britain, Germany, Canada, the Netherlands). They are used as suggestions for the convention industry and organizers for planning and executing green conventions.

Research conducted by the government and international organizations was generally conducted throughout the 2000s, and besides the aforementioned countries, the 'Sustainable Events Guide' was developed by the Department of Environment, Food and Rural Affairs in the UK to meet industrial and social needs [41]. In addition, the Federal Ministry for the Environment, Nature Conservation and Nuclear Safety in Germany approached events from a weak social point of view and published 'Guidelines for the Environmentally Sound Organization of Events' [42].

The academic studies conducted concerning the Green Convention Guidelines are as follows. Lee, Kim, and Hwang derived the Green Convention Evaluation Index and the evaluation procedure through the actual case study of Green Convention and presented an evaluation model based on 
it [16]. Sung and Lee analyzed and presented guidelines for Green MICE, which were published by international organizations, international MICE-related industrial groups, tourism-related departments, or CVB in each country, and stated that the domestic MICE industry standards should be revised and updated based on existing guidelines [8]. Lee conducted an empirical study of how eco-friendly guidelines presented in the previous study on the operation cases of convention centers in overseas are being implemented for participants in the convention center [14]. Ha and Kim analyzed the existing guidelines for green conventions presented at home and abroad and developed guidelines for green conventions suitable for Seoul [15]. In addition, Draper et al. developed sustainable guidelines for convention facilities and conducted a study to assess the importance of them, according to the conference planner [43]. Park et al. addressed the green MICE facility indicator for exhibition convention centers by analyzing the indicators and guidelines for environmentally friendly building facilities [11]. Jones developed practical guidelines for sustainable event operation management regardless of size and the style of events [44].

As the prior studies show, academic studies related to existing eco-friendly conventions are focused on evaluation models related to green conventions, green convention facility indicators, green convention guidelines, and green convention attributes, with case studies taking up the majority. Recently, empirical analysis studies have been conducted on the perspective of participants engaging in eco-friendly conventions, the impact of green convention service quality, or assessing the attributes of green conventions [7], but it seems that research regarding green convention guidelines has not been carried out continuously.

\section{Materials and Methods}

As stated in the introduction, the purpose of this study is to derive complementary points to domestic green convention guidelines. To this end, two research questions are explored in this study. The study aims to find out the difference between the guidelines for green conventions of each country. Moreover, it is attempted to investigate the deficiencies of the guidelines presented by the convention centers in Korea.

In this paper, a comparative analysis method was used to find out the characteristics and differences between green guidelines. As a first step, the composition of each convention center guideline was itemized. Then, the study was conducted through making comparisons of the identified items. At the last stage of the research method, the team made efforts to improve the clarity of the analysis results and ensure validity by conducting crosschecking among researchers.

This study was conducted on guidelines of the convention and exhibition center in the North American region, which includes the United States and Canada, Australia in Oceania, and Korea. The criteria for selecting an overseas convention center were limited to those for which convention centers that obtained the gold and platinum grade of LEED, the U.S.'s representative eco-friendly building certification system, from 2015 2019. Gold and platinum grades are awarded only when outstanding scores are obtained in seven certification assessment categories. Among them, convention centers that operate a green convention by developing their own guidelines were selected as stated in Table 1.

Table 1. The guidelines of the convention center were reviewed.

\begin{tabular}{ccc}
\hline Country & Convention Center & Guideline Title (Year of Publication) \\
\hline \multirow{2}{*}{ U.S.A } & TCF Center & TCF Center Sustainability (2018) \\
\cline { 2 - 3 } & Moscone Center & Exhibitor's Green Guide (2019) \\
\hline Canada & Vancouver Convention Centre & Sustainable Event Guidelines (2019) \\
\hline Australia & ICC Sydney & ICC Sydney Green Events Guide (2019) \\
\hline South Korea & Songdo Convensia & Green Practice Manual of Songdo \\
& Convensia (2013) \\
\hline
\end{tabular}




\section{Results}

\subsection{Energy Efficiency}

Table 2 presents the results of a comparative analysis of the energy efficiency of the facility's operating segments. The common item for all the five guidelines was lighting. They include utilizing daylight through windows and turning off unused lights. Additionally, in the electrical sector, most guidelines provide guidance on the use of energy-saving electronic devices or the minimization of the use of electronics. There was no information about heating and cooling in the Vancouver Convention Center and Songdo Convensia. The energy consumption recording was also a guideline only found in the TCF center. Therefore, the guideline of Songdo Convensia seems to be mostly focused on the use of energy-saving devices, which should be complemented by the development of programs, heating and cooling, light bulb selection, and energy consumption record.

Table 2. Guidelines for facility management-Energy efficiency.

\begin{tabular}{|c|c|c|}
\hline Facility & agement & Energy Efficiency \\
\hline \multirow[t]{2}{*}{ U.S.A } & TCF Center & $\begin{array}{ll}\text { - } & \text { Develops a program to optimize the energy consumption efficiency } \\
\text { - } & \text { Infrastructure updates, procedural and preventative maintenance } \\
\text { - } & \text { Tracks and records energy consumption and establish benchmarking goals } \\
\text { - } & \text { Induction lighting that uses } 50 \% \text { less electricity } \\
\text { - } & \text { Lighting and heating/cooling settings are computer programmed and managed } \\
\text { - } & \text { All escalators are energy efficient and run based on occupancy and event needs } \\
\text { - } & \text { Air-conditioned by pumping gray water from the Detroit River that then sends the cool water to } \\
\text { various air handlers, providing cooling to zoned areas in the center }\end{array}$ \\
\hline & $\begin{array}{l}\text { Moscone } \\
\text { Center }\end{array}$ & $\begin{array}{l}\text { - Compact fluorescent bulbs or LEDs for superior energy efficiency } \\
\text { - } \quad \text { Determine if some booth lighting can be eliminated } \\
\text { - } \quad \text { Wait until bulbs burn out before replacing them. } \\
\text { - } \quad \text { Use Energy Star certified equipment } \\
\text { - } \quad \text { Power down all electronics nightly or at least switch to sleeping mode during non-exhibition hours } \\
\text { Use auto-timed shutoff on electronic components }\end{array}$ \\
\hline Canada & $\begin{array}{c}\text { Vancouver } \\
\text { Convention } \\
\text { Center }\end{array}$ & 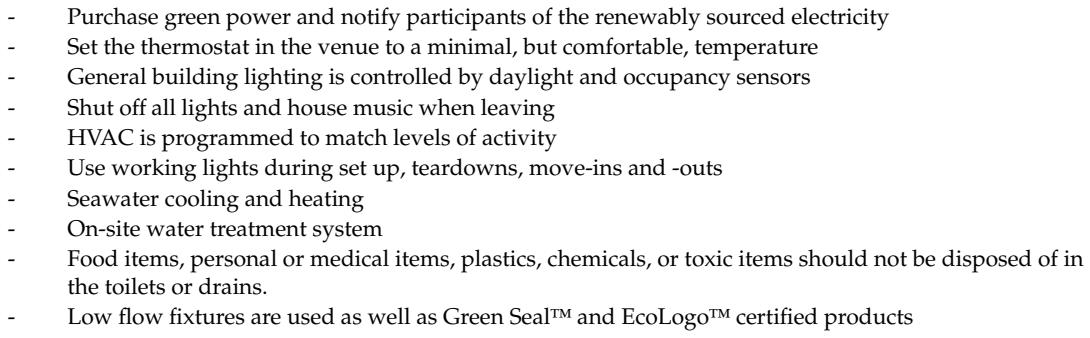 \\
\hline Australia & ICC Sydney & $\begin{array}{ll}\text { - } & \text { Request exhibitor to use lighting for stand builds } \\
\text { - } & \text { Utilize reticulated air only } \\
\text { - } & \text { Request heating and cooling to be set at reasonable temperatures } \\
\text { - } & \text { Implement a power shutdown overnight } \\
\text { - } & \text { Minimize the use of machinery }\end{array}$ \\
\hline South Korea & $\begin{array}{l}\text { Songdo } \\
\text { Convensia }\end{array}$ & $\begin{array}{l}\text { - } \begin{array}{l}\text { Designate 'employee in charge' to make employees actively participate in energy } \\
\text { conservation campaigns } \\
\text { - }\end{array} \text { Use high energy efficiency ratings or energy-saving office devices. } \\
\text { - } \quad \text { Use the laptop and switch to sleep mode during long-term absenteeism } \\
\text { - } \quad \text { Turn on and off the lamp immediately at the start and end of the event } \\
\text { - } \quad \text { Turn off unused lights } \\
\text { - } \quad \text { If there is no event, the corridor lights will be illuminated over terms } \\
\text { - } \quad \text { Use energy-efficient devices } \\
\text { - } \quad \text { Determine if it is necessary to use the air-conditioner and use it with maximum savings. }\end{array}$ \\
\hline
\end{tabular}

\subsection{Indoor Air Quality}

The result of the comparison between five green guidelines for indoor air quality is described in Table 3. In this section, the common practice in the convention centers reviewed is prohibiting smoking 
and anti-idling in the facility. The guidelines for fleet management and HVAC system monitoring are only found in the TCF center. Since Songdo Convensia does not have guidelines for indoor air quality, it should benchmark the centers that have guidelines to create manuals.

Table 3. Guidelines for facility management-Indoor air quality.

\begin{tabular}{|c|c|c|}
\hline Facility N & agement & Indoor Air Quality \\
\hline \multirow[t]{2}{*}{ U.S.A } & TCF Center & $\begin{array}{ll}\text { - } & \text { Including an anti-idling policy and enforcement } \\
\text { - } & \text { Managing VOCs and hazardous air pollutants } \\
\text { - } & \text { Fleet vehicle management and providing alternative transportation } \\
\text { - } & \text { HVAC System monitoring }\end{array}$ \\
\hline & $\begin{array}{l}\text { Moscone } \\
\text { Center }\end{array}$ & $\begin{array}{l}\text { - Smoking (as well as vaping, e-cigarette) is prohibited both inside and within } 25 \text { feet } \\
\text { of the facility. }\end{array}$ \\
\hline Canada & $\begin{array}{l}\text { Vancouver } \\
\text { Convention } \\
\text { Center }\end{array}$ & $\begin{array}{l}\text { Has established air quality control measures including prohibiting smoking within } \\
25 \text { feet }(7.5 \mathrm{~m}) \text { of the building, as well as a no-idling policy for all vehicles. As well as } \\
\text { electronic cigarettes and vaporizers }\end{array}$ \\
\hline Australia & ICC Sydney & None \\
\hline South Korea & $\begin{array}{l}\text { Songdo } \\
\text { Convensia }\end{array}$ & None \\
\hline
\end{tabular}

\subsection{Water Conservation}

Table 4 shows the comparison of water conservation of the facilities management sector. It is found that only TCF Center and ICC Sydney had green guidelines for water conservation. What the two guidelines had in common was the benchmarking method. If there is a difference, the TCF Center contains information about installing irrigation facilities, while ICC Sydney includes practices about water fountains, the use of reusable water bottles, and a post-event water report. Since Songdo does not have any guidelines for water conservation, it is desirable to benchmark the practices of other convention centers to establish guidelines.

Table 4. Guidelines for facility management-Water conservation.

\begin{tabular}{|c|c|c|}
\hline Facility & agement & Water Conservation \\
\hline \multirow[t]{2}{*}{ U.S.A } & TCF Center & $\begin{array}{l}\text { - Provide practices addressing water quality and conservation methods including } \\
\text { chemical management, landscaping and building infrastructure (toilets, sinks } \\
\text { urinals, and showers) efficiencies } \\
\text { - } \quad \text { Irrigation facility installation } \\
\text { - } \quad \text { Track and record water consumption and establish benchmarking goals }\end{array}$ \\
\hline & $\begin{array}{c}\text { Moscone } \\
\text { Center }\end{array}$ & None \\
\hline Canada & $\begin{array}{c}\text { Vancouver } \\
\text { Convention } \\
\text { Center }\end{array}$ & None \\
\hline Australia & ICC Sydney & $\begin{array}{l}\text { - Plan to provide Sydney water for delegates and attendee by booking water stations } \\
\text { across the event } \\
\text { - } \quad \text { Communicate the availability of water fountains to delegates and contractors } \\
\text { - } \quad \text { Hand out reusable water bottles as part of the event satchel for delegates } \\
\text { - } \quad \text { Encourage staff to carry reusable water bottles with them which can be refilled as } \\
\text { Sydney water stations across the venue } \\
\text { - } \quad \text { Request a post event water report from ICC Sydney } \\
\text { - Benchmark water consumption and monitor year on year }\end{array}$ \\
\hline South Korea & $\begin{array}{c}\text { Songdo } \\
\text { Convensia }\end{array}$ & None \\
\hline
\end{tabular}




\subsection{Materials}

Table 5 compares the guidelines for materials of the convention centers except for TCF center and ICC Sydney. Through this comparison, differences were clearly shown rather than commonalities. The Moscone Center focuses on choosing zero-VOC materials or avoiding PVC, polystyrene foam. The Vancouver Convention Center guideline emphasizes reusing materials and enforcing a pack-in/pack-out policy. The Songdo Convensia also has green guidelines such as preparing the list of eco-friendly building materials or regulations for the mandatory use of eco-friendly materials but needs to be supplemented due to lack of details.

Table 5. Guidelines for facility management-Materials.

\begin{tabular}{|c|c|c|}
\hline \multicolumn{2}{|c|}{ Facility Management } & \multirow[t]{2}{*}{ Materials } \\
\hline & TCF Center & \\
\hline U.S.A & $\begin{array}{l}\text { Moscone } \\
\text { Center }\end{array}$ & $\begin{array}{l}\text { - } \quad \text { Go for post-consumer content materials which are recyclable } \\
\text { - } \quad \text { Choose bamboo or wheat board material } \\
\text { - } \quad \text { Choose materials that have low volatile organic compounds } \\
\text { - } \quad \text { Flooring that meets CRI, FSC standards, or is reclaimed and repurposed } \\
\text { - } \quad \text { Use non-toxic inks on graphic panels, such as soy or vegetable-based printing inks } \\
\text { - } \quad \text { Avoid PVC, polystyrene foam materials with formaldehyde and Sintra } \\
\text { - } \quad \text { Choose zero-VOC or low VOC paints, sealants, coatings, adhesives and finishes }\end{array}$ \\
\hline Canada & $\begin{array}{l}\text { Vancouver } \\
\text { Convention } \\
\text { Center }\end{array}$ & $\begin{array}{l}\text { - Bring smaller quantities of promotional materials and offer access to electronic } \\
\text { materials on the website } \\
\text { - } \quad \text { Reuse any boxes or packaging that was used on arrival } \\
\text { - } \quad \text { with everything that was brought to the event } \\
\text { with every-ingack-out policy or zero-waste criteria to ensure exhibitors leave } \\
\text { - Use recycled content in the fabrication and assembly of display booths/exhibits for } \\
\text { future events } \\
\text { - Carefully evaluate claims of products that are identified as recyclable, recycled, } \\
\text { biodegradable or sustainable }\end{array}$ \\
\hline Australia & ICC Sydney & None \\
\hline South Korea & $\begin{array}{l}\text { Songdo } \\
\text { Convensia }\end{array}$ & $\begin{array}{l}\text { - Keep preparing and updating the list of eco-friendly building materials } \\
\text { - }\end{array}$ \\
\hline
\end{tabular}

\subsection{Waste Management}

Table 6 presents the comparative analysis of waste management of the event planning and operation field. As can be seen from the table, all the guidelines address the issue of placing recycling containers and policies for recycling/separators. Some of them also stipulate the practice for drawing a review of waste management. These convention centers differ in engaging all event participants in green practice, communicating green initiatives with visitors and contractors/providers and donation. Although Songdo also includes several common points with other guidelines, the differences mentioned above may be items that Songdo needs to supplement. 
Table 6. Guidelines for event planning and operation-Waste management.

\begin{tabular}{|c|c|c|}
\hline Event Plannir & nd Operation & Waste Management \\
\hline \multirow{2}{*}{ U.S.A } & TCF Center & $\begin{array}{l}\text { - } \quad \text { Recycling containers are placed throughout the center } \\
\text { - } \quad \text { All in-house contractors are involved in venue recycling and green initiatives } \\
\text { - } \quad \text { Recycle pallets to a local vendor } \\
\text { - } \quad \text { Ese methods to track and record waste diversion rates } \\
\text { Equipped } 180 \text { recycling stations and they are placed throughout event spaces, } \\
\text { - } \quad \text { Recycle badge holders to local charities and notify attendees with signage }\end{array}$ \\
\hline & $\begin{array}{l}\text { Moscone } \\
\text { Center }\end{array}$ & 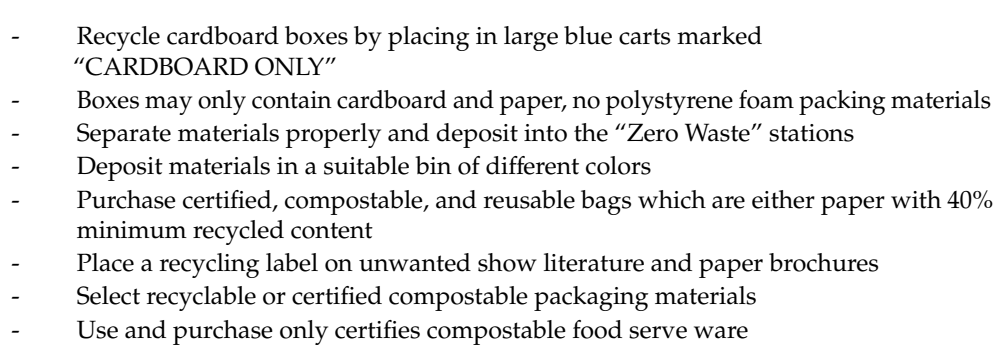 \\
\hline Canada & $\begin{array}{l}\text { Vancouver } \\
\text { Convention } \\
\text { Center }\end{array}$ & $\begin{array}{l}\text { - Place recycling containers with adequate signage } \\
\text { - Provide small trash bins at reception areas only if requested, and provide no trash } \\
\text { bins if the event's objective is zero-waste } \\
\text { - Communicate recycling/waste prevention initiatives to event participants and } \\
\text { periodically remind participants of the initiatives } \\
\text { - } \quad \text { Request digital signage if available, or use paper with recycled content }\end{array}$ \\
\hline Australia & ICC Sydney & $\begin{array}{ll}\text { - } & \text { Identify high-risk waste and develop a plan to tackle these } \\
\text { - } & \text { Seek alternatives to paper, plastics and MDF } \\
\text { - } & \text { Communicate with exhibitor, contractors and suppliers } \\
\text { - } & \text { Circulate ICC Sydney's Exhibitor Donation form } \\
\text { - } & \text { Compropriately segment waste during bump in and limit contamination } \\
\text { - } & \text { Hed appropriately } \\
\text { - } & \text { Provight the negative impact of waste contamination } \\
\text { - } & \text { Work with ICC Sydney to develop signage around bins to identify what items go in } \\
\text { - } & \text { Rhich bin } \\
\text { - } & \text { Follow } \\
\text { - } & \text { Collect lanyards, satchels, and bottles to be repurposed with one of ICC Sydney's } \\
\text { - } & \text { Semmunity partners } \\
\text { - } & \text { Share the success of waste diversion initiatives through social media }\end{array}$ \\
\hline South Korea & $\begin{array}{l}\text { Songdo } \\
\text { Convensia }\end{array}$ & $\begin{array}{ll}\text { - } & \text { Recycling is recommended } \\
\text { - } & \text { Recommended use of reusable items } \\
\text { - } & \text { Install the separator inside the center } \\
\text { - } & \text { Select the company to deal with separated and collected wastes legitimately } \\
\text { Minimize the demolition site through a drawing review to reduce the amount of } \\
\text { waste generated }\end{array}$ \\
\hline
\end{tabular}

\subsection{Signage and Promotional Materials}

Table 7 displays the comparison of signage and promotional materials of the event planning and operation. It is found that only TCF Center and ICC Sydney had green guidelines for water conservation. The standards currently common in these guidelines are that information on events is recommended to be distributed in digital formats such as CDs, online or smart devices, and use electronic media to provide the data for advertising, public relations, and registration. Songdo Convensia also has a systematic set of guidelines for promotional materials. 
Table 7. Guidelines for event planning and operation—Signage and promotional materials.

\begin{tabular}{|c|c|c|}
\hline Event Plannir & nd Operation & Signage and Promotional Materials \\
\hline \multirow[b]{2}{*}{ The U.S.A } & TCF Center & $\begin{array}{l}\text { - } \quad \text { Using signage without dates to encourage reuse } \\
\text { - } \quad \text { Distribute information about events online or in digital format }\end{array}$ \\
\hline & $\begin{array}{l}\text { Moscone } \\
\text { Center }\end{array}$ & $\begin{array}{l}\text { - } \quad \text { Layering new signage over old signage } \\
\text { - } \quad \text { Offer a "digital swag bag" for attendees rather than on-site merchandise } \\
\text { - } \quad \text { Donate the leftovers reusable promotional merchandise or materials to nonprofits } \\
\text { - } \quad \text { Eliminate dates and cities on signage and graphics for reuse }\end{array}$ \\
\hline Canada & $\begin{array}{c}\text { Vancouver } \\
\text { Convention } \\
\text { Center }\end{array}$ & $\begin{array}{l}\text { - } \quad \text { Distribute advertising, promotion, and registration materials electronically } \\
\text { - } \\
\text { - }\end{array}$ \\
\hline Australia & ICC Sydney & None \\
\hline South Korea & $\begin{array}{l}\text { Songdo } \\
\text { Convensia }\end{array}$ & $\begin{array}{l}\text { - Promotes the building as an eco-friendly building by installing signs related to LEED } \\
\text { certification and attaching power-saving/save-related stickers. } \\
\text { - Prevents the use of PET banners by installing LED electronic display panels and } \\
\text { LCD monitors } \\
\text { - } \quad \begin{array}{l}\text { Promotional materials (brochures, envelopes, etc.) should be made with eco-friendly } \\
\text { products and specify that they are "green products" }\end{array} \\
\text { - } \quad \text { In the case of DM transmission, check if waste is caused by DB redundancy } \\
\text { - } \quad \text { Use environment-friendly envelopes and adhesives (physical ingredients) } \\
\text { - } \quad \text { Rhen mailing } \\
\text { - } \quad \text { Collect the used name tag for future recycling } \\
\text { - } \quad \text { Providing event materials through CDs, online, smart devices, etc. } \\
\text { - } \quad \text { Utilize the online system for applications and documents related to events } \\
\text { - } \quad \text { Advertising and promotional activities through electronic media are encouraged }\end{array}$ \\
\hline
\end{tabular}

\subsection{Catering}

The comparative analysis of Catering in event planning and service area is provided in Table 8. As shown in the table, the TCF Center, Moscone Center and the Vancouver Convention Center deal with the issue of using compostable food containers and utensils to make food waste that is 100 percent compostable or recyclable. Songdo Convensia has a green manual that recommends preparing the list of eco-friendly catering and use of eco-friendly catering, but more detailed and deepened guidelines are required. 
Table 8. Guidelines for event planning and operation-Catering.

\begin{tabular}{|c|c|c|}
\hline Event Plannir & nd Operation & Catering \\
\hline \multirow[t]{2}{*}{ U.S.A } & TCF Center & $\begin{array}{l}\text { - Donations of unused food to local non-profits (Forgotten Harvest) and } \\
\text { employee meals } \\
\text { - } \\
\text { - } \quad \text { Work the with the chef of the TCF Center to provide local and sustainable food } \\
\text { - } \quad \text { Use compostable food containers and utensils to make } 100 \% \text { compostable or } \\
\text { recyclable food waste }\end{array}$ \\
\hline & $\begin{array}{l}\text { Moscone } \\
\text { Center }\end{array}$ & $\begin{array}{l}\text { - } \quad \text { Use only certified compostable food serving containers } \\
\text { - } \quad \text { Avoid polystyrene foam or non-recyclable serving containers }\end{array}$ \\
\hline Canada & $\begin{array}{l}\text { Vancouver } \\
\text { Convention } \\
\text { Center }\end{array}$ & 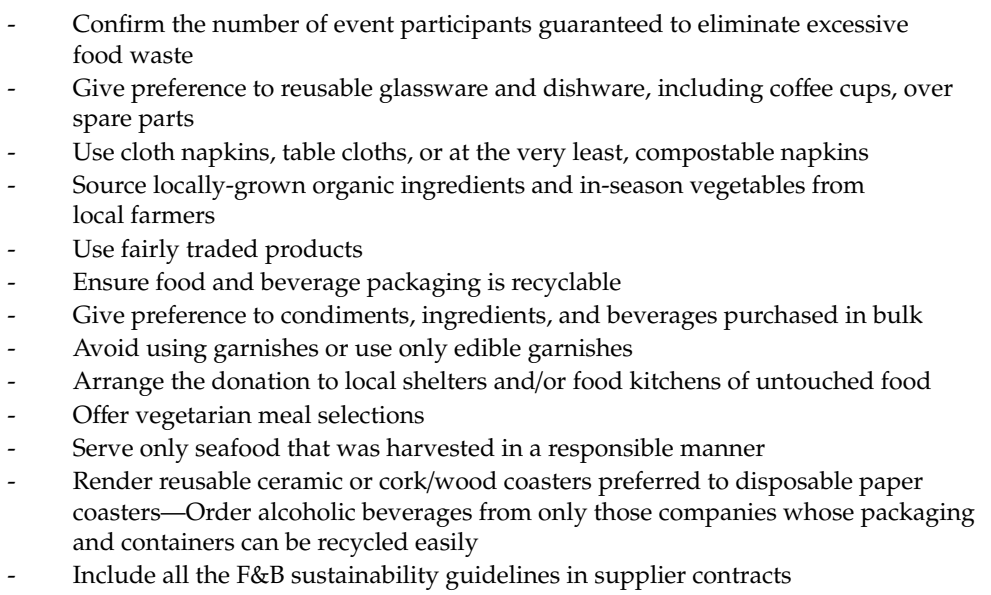 \\
\hline Australia & ICC Sydney & $\begin{array}{l}\text { - } \quad \begin{array}{l}\text { Provide accurate numbers for catering } \\
\text { - }\end{array} \quad \text { Choose menu items and beverages that utilize NSW products } \\
\text { - } \quad \text { Promote regional suppliers through signage and messaging across the event } \\
\text { - } \quad \text { Encourage attendees to utilize organic waste streams } \\
\text { - } \quad \text { Collaborate with ICC Sydney to repurpose and donate excess food }\end{array}$ \\
\hline South Korea & $\begin{array}{l}\text { Songdo } \\
\text { Convensia }\end{array}$ & $\begin{array}{l}\text { - } \quad \text { Use recyclable food and ingredients } \\
\text { - } \quad \text { Use products from the direct market, products from fair trade and produced in a } \\
\text { sustainable manner } \\
\text { - } \quad \text { Use sauces that are not individually packed } \\
\text { - } \quad \text { Use 'eatable garnish' or provide without garnish when serving food } \\
\text { - } \quad \text { For restaurants, menus should be organized as local or organic food } \\
\text { - } \quad \text { Residues should be donated to local food banks or used as fertilizer for nearby farms } \\
\text { - } \quad \text { Refrain from using disposable products such as paper cups and containers } \\
\text { - } \quad \text { Use large containers instead of individual plastic, glass and canned beverage bottles } \\
\text { - } \quad \text { If disposable beverages are provided, do not provide unnecessary glasses } \\
\text { - } \quad \text { Instead of using a teacup and a prop, use a mug } \\
\text { - } \quad \text { Refrain from using straws, paper supports, and stirring bars } \\
\text { - } \quad \text { Provide napkins at the beverage bar, but only on request } \\
\text { - } \\
\text { - } \quad \text { Put water, drinks, and seasoning sauce in a special container and use them }\end{array}$ \\
\hline
\end{tabular}

\subsection{Printing and Paper Usage}

Table 9 discusses the instructions for printing and paper usage of the convention centers. Through this comparison, it was able to find out that only three places have guidelines on printing and paper usage, which are TCF Center, Moscone Center and ICC Sydney. The center focuses on reducing paper waste by recommending participants to use the mobile app and website for the registration and downloading materials needed. Vancouver Convention Center guideline highlights the importance of using an Energy Star certified printer and vegetable-based inks. 
Table 9. Guidelines for event planning and operation-Printing and paper usage.

\begin{tabular}{|c|c|c|}
\hline Event Plannir & nd Operation & Printing and Paper Usage \\
\hline \multirow{2}{*}{ The U.S.A } & TCF Center & $\begin{array}{l}\text { - } \quad \text { To minimize paper waste, use the online event service order form on the TFC website } \\
\text { - } \quad \text { Produce less paper waste using TCF Center digital signage to alert sponsors, } \\
\text { assistant guides and agendas }\end{array}$ \\
\hline & $\begin{array}{l}\text { Moscone } \\
\text { Center }\end{array}$ & $\begin{array}{ll}\text { - } & \text { Eliminate paper literature } \\
\text { - } & \text { Invest in digital information, mobile app or website }\end{array}$ \\
\hline Canada & $\begin{array}{l}\text { Vancouver } \\
\text { Convention } \\
\text { Center }\end{array}$ & $\begin{array}{l}\text { - } \quad \text { Minimize paper usage by using online registration format } \\
\text { - Give electronic documentation preference over the paper, or use double-sided } \\
\text { copying and printing } \\
\text { - } \quad \text { Provide materials via PDA download or online where possible } \\
\text { - } \quad \text { Assess past events of similar scope and size to forecast the quantity of materials and } \\
\text { handouts required } \\
\text { - Use recycled, high }(100 \%) \text { post-consumer content paper where possible and Forest } \\
\text { - Stewardship Council certified paper } \\
\text { - Print materials on an Energy Star certified printer and use vegetable-based inks } \\
\text { Limit the use of hard to recycle paper, such as glossy paper, golden rubber and } \\
\text { florescent paper }\end{array}$ \\
\hline Australia & ICC Sydney & No separate regulations \\
\hline South Korea & $\begin{array}{l}\text { Songdo } \\
\text { Convensia }\end{array}$ & $\begin{array}{l}\text { - When printing, print as 'two-page collect' as much as possible } \\
\text { - } \quad \text { Paper that is used with one side is collected and used as a back page later on } \\
\text { - When submitting a report, reduce unnecessary pages on the cover and table } \\
\text { of contents }\end{array}$ \\
\hline
\end{tabular}

Songdo Convensia is making efforts to reduce unnecessary printing and paper usage; however, it should benchmark other green guidelines that contain practices of using online materials such as applications and PDF files.

\subsection{Transportation}

Table 10 provides the comparative analysis on transportation of the event planning and operation field. The TCF Center and the Vancouver Convention Center both carry forward the use of bicycles as a means of transportation and work with local bicycle vendors to set up bicycle rental stations to build proper bicycle storage space. Guidelines such as walking, using public transportation, and preparing carpooling areas were created at Songdo Convensia, but eco-friendly measures for transportation are needed by actively encouraging and supporting the use of bicycles. 
Table 10. Guidelines for event planning and operation-Transportation.

\begin{tabular}{|c|c|c|}
\hline Event Plannir & ad Operation & Transportation \\
\hline \multirow[t]{2}{*}{ The U.S.A } & TCF Center & $\begin{array}{l}\text { - } \quad \text { Operate a walking tour in Detroit area } \\
\text { - } \quad \text { Support the attendants to use bicycles as their transportation }\end{array}$ \\
\hline & $\begin{array}{l}\text { Moscone } \\
\text { Center }\end{array}$ & None \\
\hline Canada & $\begin{array}{c}\text { Vancouver } \\
\text { Convention } \\
\text { Center }\end{array}$ & 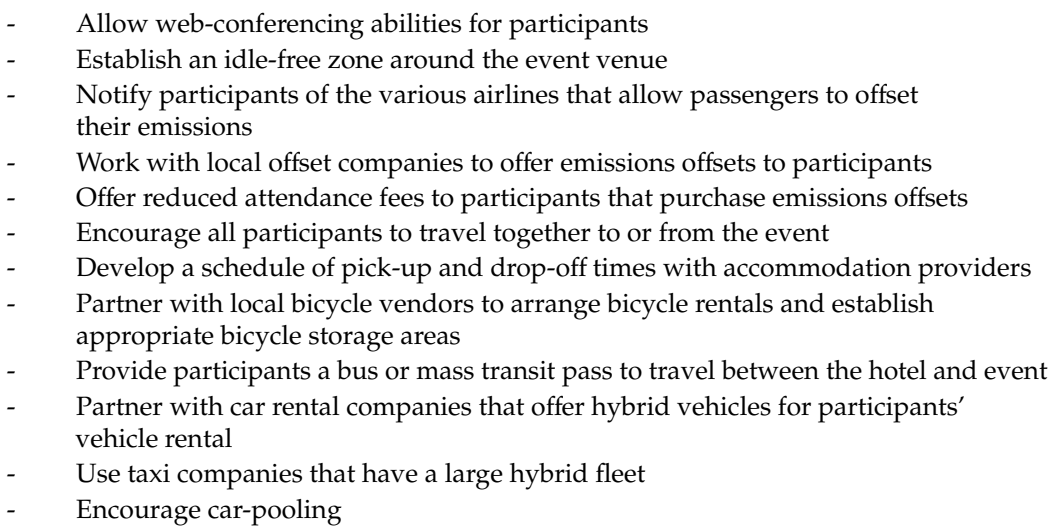 \\
\hline Australia & ICC Sydney & $\begin{array}{l}\text { - } \quad \text { Schedule deliveries and bump in with ICC Sydney's Loading Dock } \\
\text { Management System } \\
\text { - } \quad \text { Communicate green travel methods with attendees } \\
\text { - } \quad \text { Promote green travel methods } \\
\text { furvey attendees on their travel methods to benchmark an improve on in } \\
\text { - } \quad \text { Minimize congestion and overuse of vehicle }\end{array}$ \\
\hline South Korea & $\begin{array}{l}\text { Songdo } \\
\text { Convensia }\end{array}$ & $\begin{array}{ll}\text { - } & \text { Walk nearby, or use public transportation (bus, subway, etc.) } \\
\text { - } & \text { Prepare parking areas for carpooling/light vehicles } \\
\text { - } & \text { Use hybrid cars, light vehicles, etc. as work vehicles } \\
\text { - } & \text { Operate shuttle buses for large events }\end{array}$ \\
\hline
\end{tabular}

\subsection{Other}

Table 11 shows the comparison on others category of the event planning and operation. Although Songdo Convensia provides advanced operational guidelines for the compensation of green events, selects eco-friendly companies as suppliers, and continuously monitors the guidelines, it is required to benchmark initiatives from other centers that can encourage participants, employees, and organizers take part in sustainable activities. Additionally, as conducted by the TCF center, it is necessary to implement the use of products made from $50 \%$ recycled materials or boxes that can be recycled rapidly. 
Table 11. Guidelines for event planning and operation - Other.

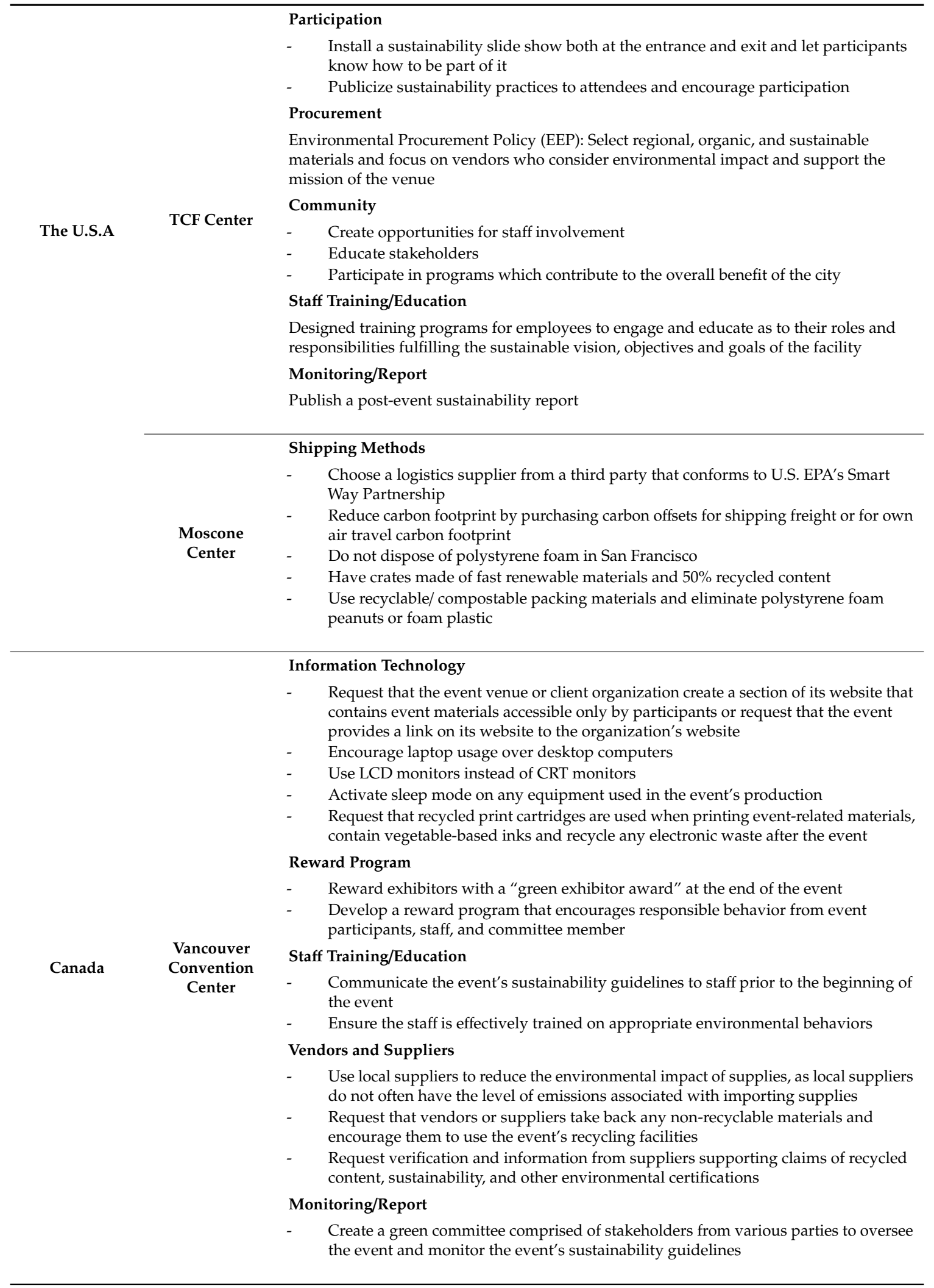


Table 11. Cont.

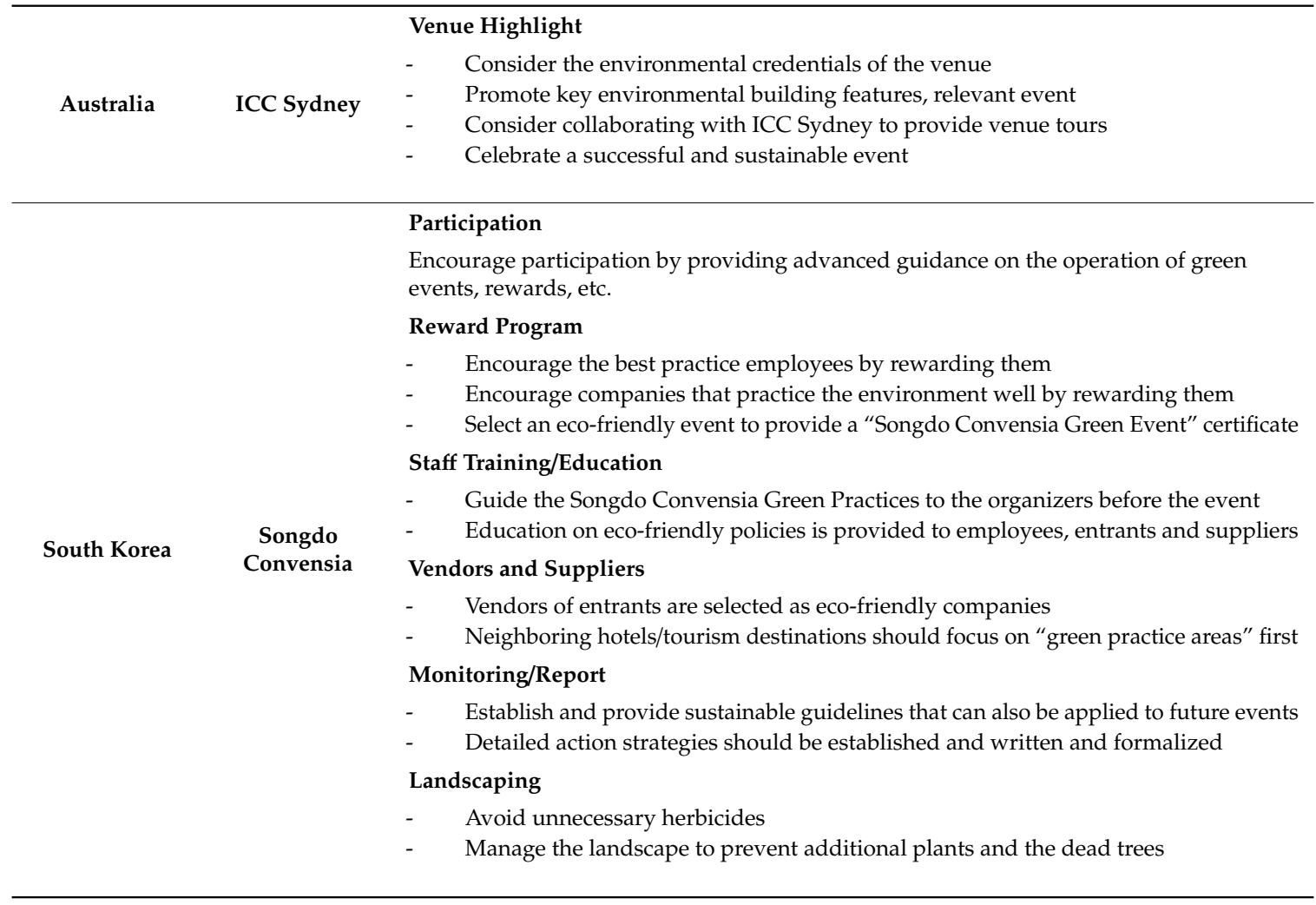

\section{Conclusions}

With the recent surge in climate problems and the severity of environmental damage worldwide, societal concern has arisen in many areas for sustainable and environmentally friendly management. Environmental-friendly awareness is also spreading in the MICE industry sector, called the new growth engine of the tourism industry, this is because there are some factors also contribute to environmental pollution in terms of the operation of convention facilities and events. This study examined the convention facilities that correspond to the seriousness of these environmental issues. The purpose of this study was to supplement domestic green convention guidelines by comparing and analyzing eco-friendly guidelines strategically implemented by domestic and foreign convention centers. Accordingly, a comparative analysis method was used to identify the similarities and differences in the green guidelines of each convention center, and within the last five years, convention centers that acquired the platinum or gold grade of LEED, a leading U.S. eco-friendly building certification system, were selected as the targets of the study. The convention centers in the United States, Canada, Australia, and Korea are included, which are operating their guidelines and drawing them into the green convention.

Before analyzing the guidelines, the comparison items were largely classified into areas of facility management and event planning and operation. The facility management sector consists of energy efficiency, indoor air quality, water conservation, and materials. The event planning and operation section were divided into waste management, signage and promotional materials, catering, printing, and paper use, transportation, and other items. According to the analysis, the contents of the green guidelines adopted by the convention centers were broadly similar. Overall, efforts were made to reduce energy consumption, ban smoking, and replace substances that cause environmental pollution with other eco-friendly substances such as desisting from using VOCs and avoiding plastic (PVCs). Moreover, they were shown to use applications and websites instead of paper when providing data and materials for events and when carrying out registration procedures to prevent reckless use of paper. The use of bicycles as a new means of transportation has been introduced, and an active bicycle 
rental service system has been created. On the other hand, there were distinct differences in the items of guidelines for each convention center. To save water, ICC Sydney has been pushing for reusable water bottles and executing water reports. At the Vancouver Convention Center, participants and employees alike were encouraged to participate in green practices to reduce waste. In sum, Songdo Convensia should benchmark the green manuals of the convention centers that were examined in this study. For example, its energy-saving operational guidelines should be extended to all parts of the facility, not just electronic devices, providing additional practices for rational use of resources. In addition, it is suggested that they should come up with operational strategies to actively engage attendees and employees in green practices for the green convention.

When looking at the preliminary study on COEX, another convention center in Korea, Lee, and Lee [45] analyzed COEX's strategy study for convention promotion and insisted on enhancing awareness and motivation for the green convention, but the study aims to reorganize and expand the guidelines for the domestic convention center by analyzing the guidelines of each convention center set by the researchers.

The study implied that while there was a previous study that proposed guidelines for green conventions, insufficient research was conducted to compare and extend the standards of the overseas convention centers to domestic convention centers.

The importance of the theoretical implication of this study is as follows: This paper presents a topic for further research in the future, as it differs from the papers previously studied in that it wants to supplement the current domestic eco-friendly certification cases and guidelines of the national and overseas convention centers.

With the MICE industry lacking guidelines related to the operation of green MICE facilities compared to its high interest in climate change or environmental issues, the complementary points presented in this study are believed to be a theoretical background when developing relevant practices and standards for green conventions drawn by tourism-related ministries, CVB and convention centers in Korea, or even criteria such as certification scheme. As shown in the study results, in contrast to the guidelines established by overseas convention centers, Songdo Convensia offers a well-organized guideline than others in Korea, but it indicates that details lag despite the numerous listed items.

However, since the content of the overseas guidelines dealt with in this study do not include a systemic description, so it is considered to be completely applicable to domestic convention centers; thus, it will positively affect the growth of green convention centers at home and the sustainability of eco-friendly events.

The practical implications of this study are as follows: due to the inadequate prior research by applying the advantages overseas convention centers' guidelines to the manuals of the domestic convention centers, and the findings can help not only those who work at the Songdo Convensia but also those who work at other convention centers in Korea. It is also meaningful that convention center workers can further maximize the operation of green convention centers by applying the outcomes and it plays a major role in developing their guidelines later on.

This study compared the green guidelines of various convention centers in four different countries to show their features, commonalities, and differences, and to derive complementary points to the guideline of Songdo Convensia in Korea. Despite the observations and consequences set out above, a few limitations appeared. In the process of selecting the objectives for exploratory research, the study failed to compare the more diverse countries because only convention centers that had obtained LEED platinum or gold ratings within the past five years have been considered.

Further, the relatively small number of green guidelines was published, and the lack of studies related to the sustainability of convention centers has become limiting points for in-depth research.

Therefore, future studies require in-depth studies that will resolve the limitations of this study by choosing relevant subjects in a wider scope. Additionally, the verification of conformity is required not only by the researchers who conducted the study, but also surveys of experts and the public who use the convention center. Finally, it would be more meaningful as an academic material if further studies 
were carried out that would develop a practical use of the guidelines provided in this study for the green convention.

Author Contributions: Conceptualization, All; methodology, M.K.; investigation, H.M. and M.C.; writing —original draft preparation, H.M., M.C. and M.K.; writing—review and editing, M.K. and Y.Y.; supervision, M.K. and Y.Y. All authors have read and agreed to the published version of the manuscript.

Funding: This work was supported by the BK21 plus program through the National Research Foundation (NRF) funded by the Ministry of Education of Korea.

Conflicts of Interest: The authors declare no conflict of interest.

\section{References}

1. Kim, C.W. The Present Status and Development Direction of MICE Industry. Korea Tour. Policy 2016, 64, $10-19$.

2. McCartney, G. The Casino Tourism (CAT) and the Meetings, Incentives, Conventions, Exhibitions (MICE): Key Development Considerations for the Convention and Exhibition Industry in Macao. J. Conv. Event Tour 2008, 9, 293-308. [CrossRef]

3. Han, J.H.; Kim, C.W.; Sim, S.H. Qualitative Case Study for Sustainability Management in Korean and US Convention Centers. J. Tour. Leis. Res. 2015, 27, 453-472.

4. Mair, J.; Jago, L. The development of a conceptual model of greening in the business events tourism sector. J. Sustain. Tour. 2010, 18, 77-94. [CrossRef]

5. Miller, G. Corporate Responsibility in the UK Tourism Industry. Tour. Manag. 2001, 22, 589-598. [CrossRef]

6. Lynes, J.; Dredge, D. Going Green: Motivations for Environmental Commitment in the Airline Industry, A Case Study of Scandinavian Airlines. J. Sustain. Tour. 2010, 14, 116-138. [CrossRef]

7. Lee, E.S. The effect of Green MICE Service Quality Attributes on the Evaluation of Service Quality and Participants' Satisfaction: Focusing on Comparison of Convention and Exhibition. J. Hotel Resort 2018, 17, $117-133$.

8. Seong, E.H.; Lee, H.J. An Exploratory Study for Analysis of Guidelines for Green MICE. Event Conv. Res. 2010, 6, 45-62.

9. Guidelines for Environmentally Friendly Management and Operations of Large-scale International Conference. Available online: http://me.go.kr/home/web/main.do (accessed on 23 December 2019).

10. Park, H.Y.; Kim, D.K. Study on Developing Guidelines for Green Exhibition and Convention Center. J. Tour. Leis. Res. 2012, 24, 419-433.

11. Park, H.Y.; Kim, D.K.; Kim, B.S. A Study on Guideline Development for Green MICE Facilities: Focusing on Location and Building Management of Exhibition \& Convention Centers. Korean J. Hosp. Tour. 2015, 24, 23-37.

12. Kim, I.S.; Hyun, S.H. The Impacts of Convention Center's Community Connection, Technical Capability, Managerial Capability and Global Network on Perceived Innovativeness and Convention City's Identity Attractiveness: A Moderating Role of Destination Image as Ocean City. Korean J. Hosp. Tour. 2013, 22, 205-220.

13. Hwang, H.G.; Lee, S.Y. A study on Operation and Establish Guideline of Green Convention. J. Mice Tour. Res. 2009, 9, 137-170.

14. Lee, H.S. A Study on Developing Green Convention for the 21st Century. Int. J. Tour. Hosp. Res. 2010, 24, 129-144.

15. Ha, M.H.; Kim, C.W. A study on the development of Seoul green convention guideline. J. Mice Tour. Res. 2011, 11, 29-46.

16. Lee, H.J.; Kim, K.L.; Hwang, H.G. An Exploratory Study for the Evaluation Model of Green Convention. J. Mice Tour. Res. 2008, 8, 51-74.

17. Sun, J.G. A Study on the Structural Relationships among Convention Participants Satisfaction with Green Convention, Corporate Attentiveness and Behavioral Intentions: Focused on Changwon Exhibition Convention Center. J. Tour. Leis. Res. 2018, 30, 249-263.

18. Ahn, S.H. Preface to the research methodology of comparative social policy. J. Crit. Soc. Welf. 2002, 13, 47-71. 
19. Sartori, G. Compare Why and How: Comparing Miscomparing and the Comparative Method, Comparing Nations: Concepts, Strategies, Substance; Blackwell: Oxford, UK, 1994; pp. 14-34.

20. Allardt, E. Challenges for Comparative Social Research. Acta Sociol. 1990, 33, 183-193. [CrossRef]

21. Won, J.Y.; No, S.R. Status of LEED Certified Buildings in Korea and its Energy Consumption. Rev. Archit. Build. Sci. 2019, 39, 562.

22. Gracan, D.; Barkidija, M.; Dugandzic, A. An Exploratory study of environmental awareness in business tourism. Tourism \& Hospitality Industry University of Rijeka. Fac. Tour. Hosp. Manag. 2016, 05, 53-65.

23. Lee, J.M.; Breiter, D.; Choi, Y.S. Quality of a green destination as perceived by convention attendees: The relationship between greening and competitiveness. In Proceedings of the Graduate Student Research Conference in Hospitality and Tourism, Shah Alam, Selangor, Malaysia, 1 January 2011.

24. Han, H.S.; Kim, W.S.; Hyun, S.H. Switching intention model development: Role of service performances, customer satisfaction, and switching barriers in the hotel industry. Int. J. Hosp. Manag. 2011, 30, 619-629. [CrossRef]

25. Whitfield, J.; Dioko, L.A.N.; Webber, D.E. Scoring environmental credentials: A review of UK conference and meetings venues using the greener venue framework. J. Sustain. Tour. 2014, 22, 299-318. [CrossRef]

26. Wu, H.C.; Cheng, C.C.; Hong, W. An empirical analysis of green convention attendees' switching intentions. J. Conv. Event Tour. 2017, 18, 159-190. [CrossRef]

27. Lee, W.J.; Barber, T.; Tyrrell, T. Green attendees'evaluation of green attributes at the convention Centre: Using importance-performance analysis. Anatolia 2013, 24, 221-240. [CrossRef]

28. Green Meeting Guide. Available online: www.unep.fr/scp/sun (accessed on 23 December 2019).

29. Green Meetings Report. 2004. Available online: www.conventionindustry.org/Files/CIC_Green_Meetings_ Report.pdf (accessed on 23 December 2019).

30. Park, H.Y.; Kim, D.K. In pursuit of an environmentally friendly convention industry: A sustainability framework and guidelines for a green convention. Int. J. Contemp. Hosp. Manag. 2017, 29, 1028-1051. [CrossRef]

31. Choi, H.J.; Kim, J.Y. Convention Participants' Environmental Awareness, Acceptance of Environment-friendly Convention Attributes, and Intention to Participate. J. Korea Contents Assoc. 2011, 11, 431-441. [CrossRef]

32. Bae, J.H.; Lee, J.G. The Research of Available and Sustainable Space in Convention Exhibitions. J. Korea Inst. Spat. Des. 2016, 11, 39-50.

33. Wang, K.R. A Study on Scale Development of Green Convention. Mater's Thesis, Dongui University, Busan, Korea, 2013.

34. Green Practice Manual of Songdo Convensia. Available online: www.travelicn.or.kr/open_content/ (accessed on 23 December 2019).

35. Daniel, C.; Douglas, S.; Anna, M. Performance or Marketing Benefits? The Case of LEED Certification. Environ. Sci. Technol. 2014, 48, 2001-2007.

36. Choi, D.H. Analysis of Scoring Status and Adoption Characteristics by Evaluation Items based on LEED Canada Certified Cases. Rev. Korea Inst. Archit. Sustain. Environ. Build. Syst. 2018, 12, 655-668.

37. Liu, T.-Y.; Chen, P.-H.; Chou, N.N.S. Comparison of Assessment Systems for Green Building and Green Civil Infrastructure. Sustainability 2019, 11, 2117. [CrossRef]

38. Nho, J.H.; Lee, E.S. Effects of the physical environment of a LEED-certified green restaurant on customers perceived value, satisfaction, and loyalty. Int. J. Tour. Manag. Sci. 2017, 32, 23-41.

39. USGBC. Green building 101. 2016. Available online: http://www.usgbc.org/articles/greenWalsman (accessed on 14 April 2020).

40. Jung, S.S.; Yoon, J.H. LEED—Oriented Environmental Management have an Impact on Hotel Image and Behavioral Intention. J. Tour. Leis. Res. 2013, 25, 229-247.

41. Sustainable Events Guide. Available online: www.emfevents.co.uk/uploads/SustainableEventsGuide.pdf (accessed on 23 December 2019).

42. Guidelines for the Environmentally Sound Organization of Events. Available online: www.bmu.de/en (accessed on 3 January 2020).

43. Draper, J.; Dawson, M.; Casey, E. An exploratory study of the importance of sustainable practices in the meeting and convention site selection process. J. Conv. Event Tour. 2011, 12, 153-178. [CrossRef] 
44. Jones, M. Sustainable Event Management: A Practical Guide, 3rd ed.; Earthscan: London, UK, 2007.

45. Lee, Y.B.; Lee, H.J. A Study on the Strategies for Environment-Friendly Promotion of Exhibition and Convention Industry Focus on COEX's Green Convention. J. Conf. Trade Sch. 2008, 248-272.

(C) 2020 by the authors. Licensee MDPI, Basel, Switzerland. This article is an open access article distributed under the terms and conditions of the Creative Commons Attribution (CC BY) license (http://creativecommons.org/licenses/by/4.0/). 